Taxonomy and systematics

\title{
New species of waterbear Minibiotus pentannulatus (Tardigrada: Macrobiotidae) from Colombia
}

\author{
Nueva especie de osito de agua Minibiotus pentannulatus (Tardigrada: Macrobiotidae) de Colombia \\ Rosana Londoño $^{\mathrm{a}, *}$, Anisbeth Daza ${ }^{\mathrm{a}}$, Oscar Lisi ${ }^{\mathrm{b}}$, Sigmer Quiroga $^{\mathrm{c}}$ \\ ${ }^{a}$ Grupo de Investigación MIKU, Universidad del Magdalena, Carrera 32 Núm. 22-08, Santa Marta D.T.C.H., Colombia

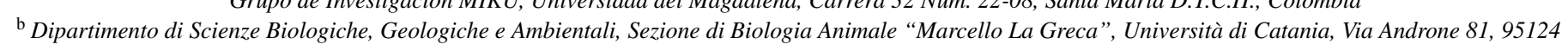 \\ Catania, Italy \\ ${ }^{\text {c } F a c u l t a d}$ de Ciencias Básicas, Programa de Biología, Universidad del Magdalena, Carrera 32 Núm. 22-08, Santa Marta D.T.C.H., Colombia
}

Received 14 December 2016; accepted 17 May 2017

Available online 21 November 2017

\begin{abstract}
The new species Minibiotus pentannulatus sp. nov., is described from the Sierra Nevada de Santa Marta, Colombia. It differs from the other species of the genus by star-shaped pores, the presence of a peculiar egg with a smooth shell, and small conical processes with 5 annulations. Other differences include the distribution and size of the pores, and other morphometric details regarding the size of the body and buccal tube, and the $p t$ of the stylet support insertion point, macroplacoids and claws. To date, the genus Minibiotus R.O. Schuster, 1980, comprises 48 species, including the species described here.

(C) 2017 Universidad Nacional Autónoma de México, Instituto de Biología. This is an open access article under the CC BY-NC-ND license (http://creativecommons.org/licenses/by-nc-nd/4.0/).
\end{abstract}

Keywords: Biodiversity; Magdalena; Sierra Nevada de Santa Marta; Tardigrades

\section{Resumen}

Se describe la nueva especie Minibiotus pentannulatus sp. nov., proveniente de la Sierra Nevada de Santa Marta, Colombia. Ésta difiere de las otras especies del género por los poros en forma de estrella, la presencia de huevos característicos con cáscara lisa y procesos cónicos con 5 anillos. Otras diferencias incluyen la distribución y talla de los poros y otros detalles morfométricos. Hasta la fecha, el género Minibiotus R.O. Schuster, 1980, comprende 48 especies, incluyendo la especie aquí descrita.

(C) 2017 Universidad Nacional Autónoma de México, Instituto de Biología. Este es un artículo Open Access bajo la licencia CC BY-NC-ND (http://creativecommons.org/licenses/by-nc-nd/4.0/).

Palabras clave: Biodiversidad; Magdalena; Sierra Nevada de Santa Marta; Tardígrados

\section{Introduction}

The genus Minibiotus R.O. Schuster, 1980, currently comprises 47 species (Degma, Bertolani, \& Guidetti, 2017). This genus is characterized by the presence of an antero-ventral mouth with 10 peribucal papulae but without lamellae; short, rigid, and narrow buccal tube usually with 2 bends; relative

\footnotetext{
* Corresponding author.

E-mail address: rosanalondono@gmail.com (R. Londoño).

Peer Review under the responsibility of Universidad Nacional Autónoma de México.
}

cephalic stylet support insertion point; and an extra thickening on the wall of the buccal tube immediately below the stylet support insertion point (Claxton, 1998; Michalczyk \& Kaczmarek, 2004).

In Colombia, tardigrades have been poorly studied. To date, 52 species have been recorded for the country (Caicedo, Londoño, \& Quiroga, 2014; Kaczmarek, Michalczyk, \& McInnes, 2015; Lisi, Londoño, \& Quiroga, 2014; Lisi, Daza, Londoño, \& Quiroga, 2017; Londoño, Daza, Caicedo, Quiroga, \& Kaczmarek, 2015; Melo, Beltrán-Pardo, Bernal, \& Kaczmarek., 2015; Stec, Roszkowska, Kaczmarek, \& Michalczyk, 2017), from which only 2 belong to the genus Minibiotus. The 
genus was recorded for the first time in Colombia, by Heinis (1914) with the species Minibiotus intermedius (Plate, 1888) that should be referred to as "sensu lato" according to modern taxonomic achievements. A century later in 2014, Minibiotus cf. pilatus Claxton, 1988 (Lisi et al., 2014), was reported in the Department of Magdalena, more precisely in the Sierra Nevada de Santa Marta (SNSM). This is an isolated costal mountain with high biological richness of species; $39.6 \%$ of the species of tardigrades recorded in Colombia have been found in this region. Herein, we describe the new species Minibiotus pentannulatus sp. nov. from SNSM, Colombia.

\section{Materials and methods}

A single sample of lichens growing on a tree trunk was collected on March 21st 2015 from El Campano, Department of Magdalena at 1,334 m asl in the Sierra Nevada de Santa Marta. This sample, included in the framework of the research project "Composición taxonómica de flora y fauna anhidrobiótica en microdoseles de la Sierra Nevada de Santa Marta" has been legally collected under the permit "Permiso Marco de Recolección de Especímenes de Especies Silvestres de la Diversidad Biológica con fines de investigación científica no comercial", resolution 1293 (2013), expedited by the Autoridad Nacional de Licencias Ambientales (ANLA) granted to the Universidad del Magdalena. The sample was kept in a paper bag, then rehydrated for $48 \mathrm{~h}$ with bottled water and examined using a Zeiss Stemi DV4 dissecting stereoscope. Tardigrades and eggs were extracted with micropipettes and mounted directly in PVA mounting media (BioQuip \#6371A) for examination under a Phase Contrast Microscope (PCM) Zeiss Axiolab A1. Identification, using taxonomic keys, was based on morphological characters. Literature used in the identification included: Pilato and Binda (2010) for genus identification, and descriptions of several species (Binda \& Pilato, 1992; Claxton, 1998; Meyer \& Hinton, 2009; Michalczyk \& Kaczmarek, 2003, 2004; Murray, 1910; Pilato, Binda, \& Lisi, 2003; Rossi, Claps, \& Ardohain, 2009; Roszkowska, Stec, Ciobanu, \& Kaczmarek, 2016).

Photos were taken with CCD camera Zeiss AxioCam ERc $5 \mathrm{~s}$. All measurements are given in micrometers $(\mu \mathrm{m})$ and were acquired with the software Zeiss AxioVision SE64. For the description of the new species, measurements of the taxonomically important structures were provided only when they were undamaged and in a suitable position. Buccal tube length was measured according to Pilato (1981). Lengths of primary and secondary branches of claws were measured from base to apex, including accessory points. The $p t$ ratio is the ratio of the length of a given structure to the length of the buccal tube, expressed as a percentage (Pilato, 1981). All pt values are in square brackets.

The Minibiotus population was composed by specimens between $144 \mu \mathrm{m}$ and $258 \mu \mathrm{m}$ body length. Therefore, the new Minibiotus specimens were assigned to 3 different life stages. The smallest specimens were attributed to the first life stage and correspond to those with buccal tube and claw lengths similar to the embryo inside the egg (about $19 \mu \mathrm{m}$ and $4.5-5 \mu \mathrm{m}$ respectively); these also showed a remarkable arrangement of the star-shaped pores in 8 single transverse rows along the body.
The specimens placed in the second life stage were those of intermediate size (approx. 180-203 $\mu \mathrm{m}$ ). Specimens in this group maintain the 8 single transverse rows of pores still recognizable, but less evident than the first stage specimens due to the presence of some extra pores randomly distributed between the rows. Finally, the third life stage corresponds to the biggest specimens (about 205-258 $\mu \mathrm{m}$ ), which did not show any trace of the initial arrangement of the pores, being randomly distributed in the entire body.

\section{Description}

Class: Eutardigrada Ritchers, 1926

Order: Parachela Schuster, Nelson, Grigarick \& Christenberry, 1980

Superfamily: Macrobiotoidea Thulin, 1928 in Marley et al. 2011

Family: Macrobiotidae Thulin, 1928

Genus: Minibiotus R.O. Schuster, 1980

Minibiotus pentannulatus sp. nov. (Figs. 1-3, Table 1)

Species diagnosis. Eye-spots absent after slide mounting. Body colorless with smooth cuticle, only with a fine granulation on legs IV. Entire cuticle including the legs, with numerous pores variable in shape: rounded, oval, multi-lobated (3-4 tips), and star-shaped (5-6 tips). The rounded and oval are smaller $(0.49-1.79 \mu \mathrm{m})$ than the multi-lobated and star-shaped pores $(1.35-2.84 \mu \mathrm{m})$. The multi-lobated and star-shaped pores are bigger at the cephalic and caudal extremities of the body and on the legs. In the specimens found in early life stages, these pores form 8 transverse single rows, and a cluster of pores in the cephalic and caudal region, on the dorsal and ventral cuticle, which are no longer recognizable in older specimens due to the apparition of other pores among the rows (Fig. 3A and B).

Teeth in the oral cavity absent or not visible under PCM. Buccal apparatus of the Minibiotus type. Buccal tube with 2 bends which are only evident in lateral view; well-developed ventral lamina, 3 granular macroplacoids and a microplacoid, pharyngeal bulb rounded. Claws of the hufelandi type with welldeveloped accessory points. Smooth lunules. Eggs laid freely, egg surface smooth, with numerous short conical processes with 5 transverse concentrical ridges appearing as thickened annulations.

Description of the holotype: Colorless, body length $206 \mu \mathrm{m}$, although this measurement should be higher because of the retraction of the mouth (Fig. 1A). Without eye-spots after slide mounting. Smooth cuticle with only a fine, and slightly evident granulation on the hind legs. Cuticle covered with numerous pores distributed irregularly, variable in shape and size, rounded, and oval $(0.49-1.57 \mu \mathrm{m})$, and multi-lobated and star-shaped $(1.35-2.66 \mu \mathrm{m})$. The biggest star-shaped pores are more commonly present on the cephalic and caudal extremities of the body, and on the legs. Pores around the mouth seem to be absent.

Mouth antero-ventral. Peribuccal papulae are present, peribuccal lamellae absent. Buccopharyngeal apparatus of the Minibiotus type (Fig. 1B). Teeth in the oral cavity absent or not visible under PCM. Rigid buccal tube, $27.6 \mu \mathrm{m}$ long and $2.3 \mu \mathrm{m}$ of external width [8.3] with anterior and posterior bends; 

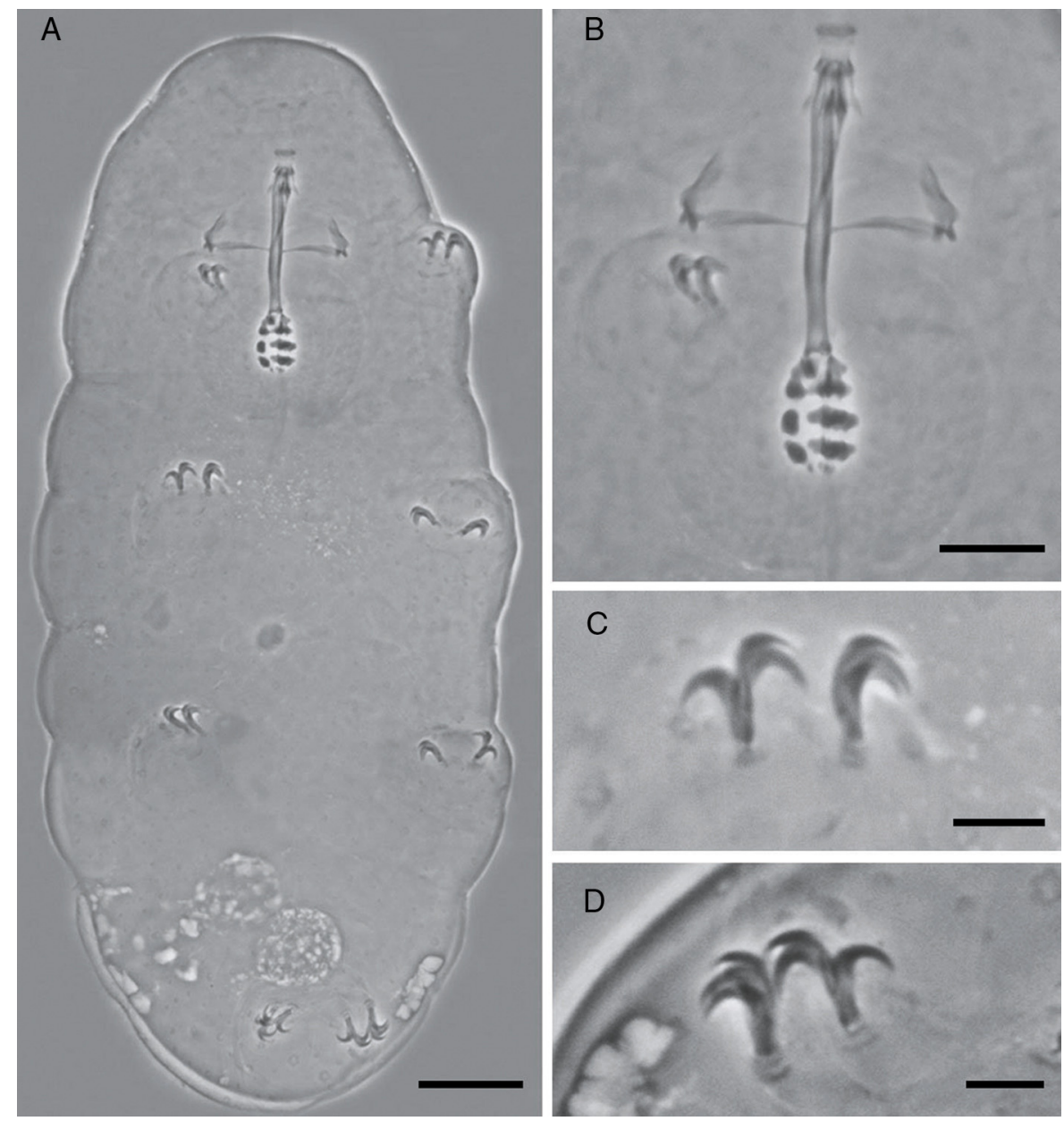

Figure 1. Holotype of Minibiotus pentannulatus sp. nov. (A) Habitus (scale bar $20 \mu \mathrm{m}$ ). (B) Detail of the buccal tube (scale bar $10 \mu \mathrm{m}$ ). (C) Detail of the claws of the second pair of legs (scale bar $5 \mu \mathrm{m}$ ). (D) Detail of the claws of the fourth pair of legs (scale bar $5 \mu \mathrm{m}$ ).

well-developed ventral lamina $13.1 \mu \mathrm{m}$ [47.5]. Stylet support inserted on the buccal tube at $15.9 \mu \mathrm{m}$ [57.6]. Rounded pharyngeal bulb $32.29 \mu \mathrm{m}$, with triangular apophyses close to the first row of macroplacoids. Three rows of macroplacoids decreasing in size, with granular appearance and a row of small microplacoids. First macroplacoid $3.0 \mu \mathrm{m}$ [10.9], second macroplacoid $2.5 \mu \mathrm{m}$ [9.1], third macroplacoid 2.1 $\mu \mathrm{m}$ [7.6]. Microplacoid, $0.9 \mu \mathrm{m}$ [3.3]. Macroplacoid row is $8.0 \mu \mathrm{m}$ [29.0], entire placoid row is $9.2 \mu \mathrm{m}$.

Claws of hufelandi type. Primary branches with welldeveloped accessory points (Fig. 1C and D). Claw lengths: leg I, external primary branch $6.3 \mu \mathrm{m}$ [22.8]; internal primary branch $6.3 \mu \mathrm{m}$ [22.8], internal secondary branch $4.6 \mu \mathrm{m}$ [16.7]. Leg II, external primary branch $6.3 \mu \mathrm{m}$ [22.8], external secondary branch $4.6 \mu \mathrm{m}$ [16.7]; internal primary branch $6.1 \mu \mathrm{m}$ [22.1]. Leg III, external primary branch $6.1 \mu \mathrm{m}$ [22.1], exter-

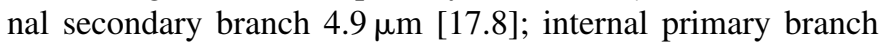
$6.2 \mu \mathrm{m}$ [22.5]. Leg IV, anterior primary branch $7.5 \mu \mathrm{m}$ [27.2], anterior secondary branch $5.9 \mu \mathrm{m}$ [21.4]; posterior primary branch $7.6 \mu \mathrm{m}$ [27.5], posterior secondary branch $6.0 \mu \mathrm{m}$ [21.7]. Smooth lunules. Cuticular bars present.

Egg: only 1 embryonated egg was found (Fig. 2B). White, spherical, and laid freely. Diameter $74.5 \mu \mathrm{m}$ (Fig. 2A). Processes without reticulation, but with 5 transverse concentrical ridges which appear as thickened annulations. Egg shell among processes smooth (Fig. 2C).

The measurements of selected morphological structures of the holotype and the ranges within the population are given in Table 1.

\section{Taxonomic summary}

Material examined: holotype, 37 paratypes, 7 simplex specimens, and 1 egg in PVA mounting media (BioQuip \#6371A). All specimens were found in a single sample, which was a mixture of lichens from the genera Hypotrachyna, Heterodermia, and Parmotrema, growing on a tree trunk. Locality: El Campano $11^{\circ} 06^{\prime} 32.2^{\prime \prime} \mathrm{N}, 74^{\circ} 05^{\prime} 31.1^{\prime \prime} \mathrm{W}, 1,334 \mathrm{~m}$ asl, Sierra Nevada de Santa Marta, Department of Magdalena, Colombia.

Type repositories: the holotype, paratypes, and egg are deposited in the Centro de Colecciones Biológicas de la Universidad del Magdalena (CBUMAG), Santa Marta, Colombia. Slide numbers: holotype: CBUMAG:TAR:00447; paratypes: CBUMAG:TAR:00437 (6 specimens), TAR:00438 (2 specimens), TAR:00439 (6 specimens), TAR:00440 (5 specimens), TAR:00441 (5 specimens), TAR:00442 (3 

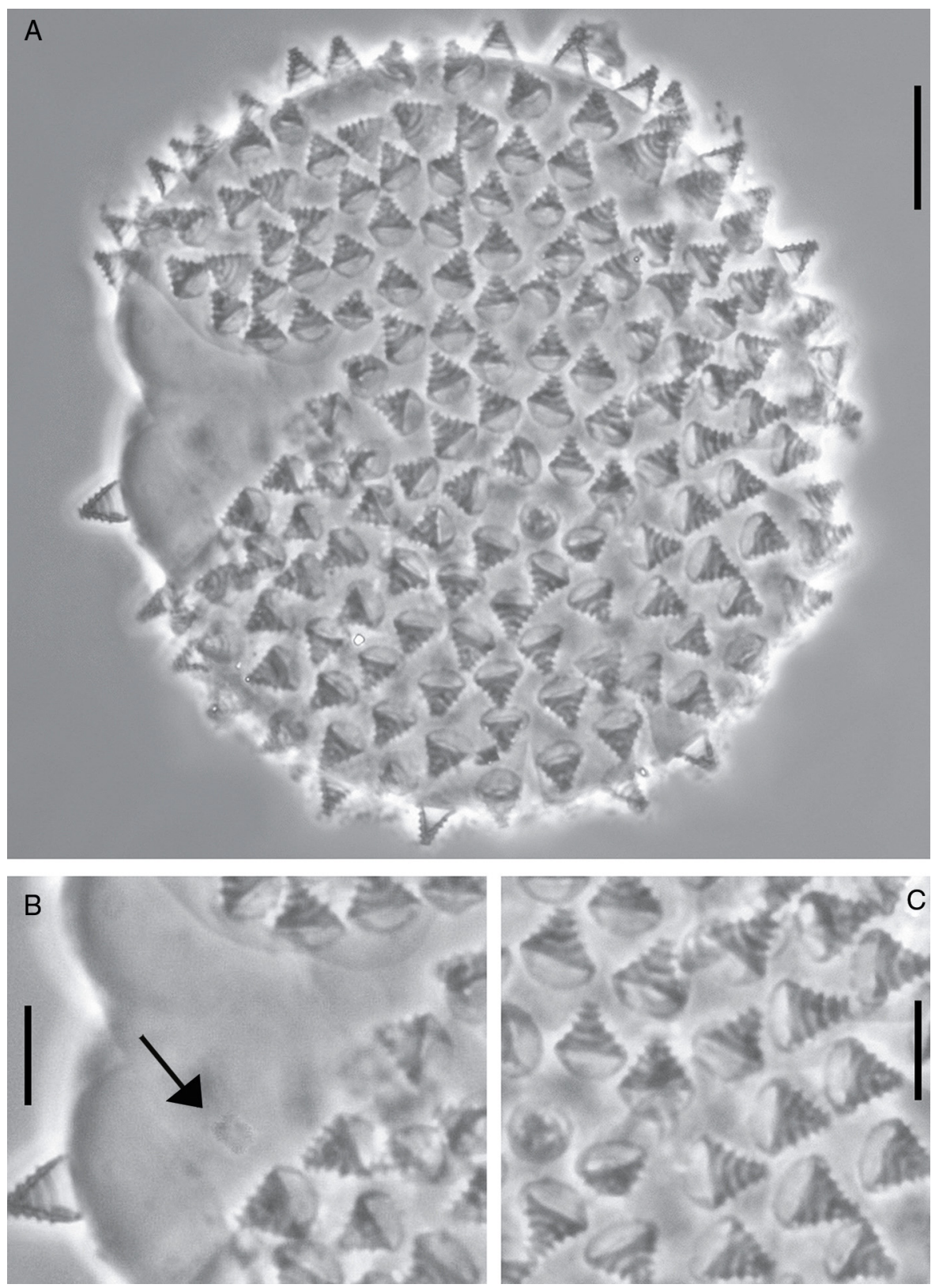

Figure 2. Egg of Minibiotus pentannulatus sp. nov. (A) General view (scale bar $10 \mu \mathrm{m}$ ). (B) Detail of the cuticle of the embryo, arrow indicates a multi-lobated pore (scale bar $5 \mu \mathrm{m}$ ). (C) Detail of the smooth eggshell and the processes with 5 annulations (scale bar $5 \mu \mathrm{m}$ ).

specimens), TAR:00443 (1 specimen), TAR:00444 (2 specimens), TAR:00445 (1 specimen), TAR:00446 (3 specimens), TAR:00447 (1 specimen), TAR:00448 (7 specimens), TAR:00449 (2 specimens); egg: CBUMAG:TAR:00450.

Etymology: the specific epithet refers to the presence of 5 (penta) rings (annuli) on the egg processes: "pentannulatus" = provided with 5 annuli.

\section{Taxonomic remarks}

The $p t$ ranges of the placoid lengths appear quite high within a species. However, we would like to emphasize that such small and peculiarly shaped (i.e., typical of Minibiotus species with 3 macroplacoids) placoids were often difficult to measure with total certainty. Additionally, our population was composed of hatchlings and specimens in the second, and most likely third stages. Although allometry was not verified, we cannot exclude the fact that some metric differences were due to allometric growing of structures in the first life stages.

Apart of the distribution of the smallest pores, the paratypes showed the same characters of the holotype. The specimens in which the multi-lobated/star-shaped pores formed the 8 transverse single rows, and a cluster of pores in the cephalic (anterior to the row 1) and caudal region (posterior to the row 8) (Fig. 3A), were those in the first life stage, body length between $144 \mu \mathrm{m}$ and 

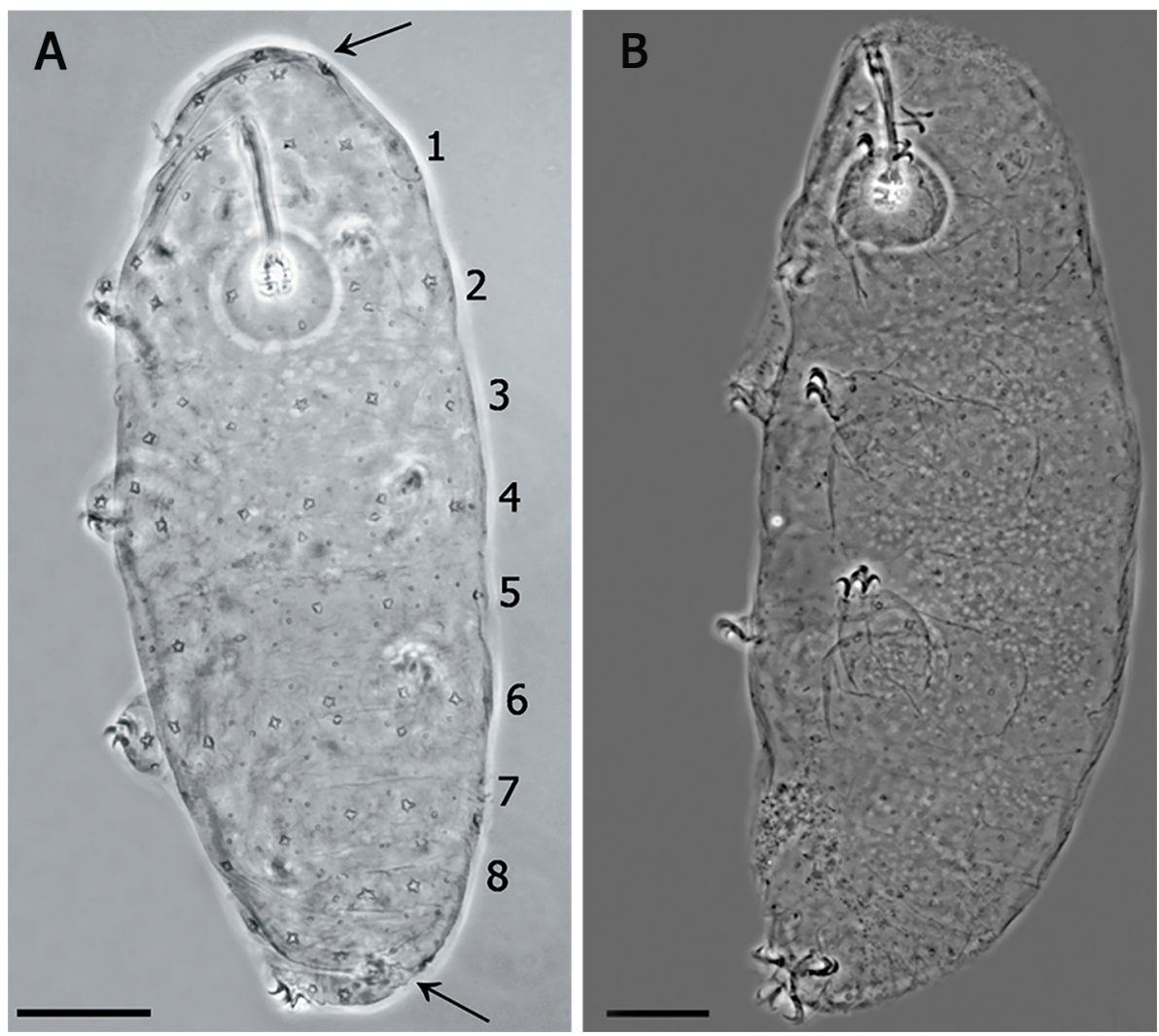

Figure 3. (A) Juvenile in the first stage of life, showing the pattern of 8 bands of pores on its cuticle (scale bar $20 \mu \mathrm{m}$ ). Arrows indicate the cluster of pores in the cephalic (anterior to the row 1) and caudal region (posterior to the row 8). (B) Specimen in third life stage showing the pores scattered on the cuticle.

$169 \mu \mathrm{m}$ and/or buccal tube length similar to that of the embryo in the egg. In specimens about $200 \mu \mathrm{m}$, in the second life stage, the bands are no longer made of a single row of pores and the pattern is less defined. Larger specimens (third life stage) do not show any pattern, having a multi-lobated and star-shaped pores randomly distributed (Fig. 3B).

The egg of $M$. pentannulatus sp. nov. is unique not only within the genus Minibiotus but also compared to all eutardigrades. It resembles the eggs of the species Calcarobiotus (Calcarobiotus) digeronimoi Pilato, Binda \& Lisi, 2004a, C. (Calcarobiotus) imperialis Abe \& Takeda, 2000, and C. (Discrepunguis) tetrannulatus Pilato, Binda \& Lisi, 2004b, because of the presence of annulations on the processes; however, the egg shell of M. pentannulatus sp. nov. is smooth, while in those species it is reticulated (Abe \& Takeda, 2000; Pilato, Binda, \& Lisi, 2004a, 2004b). Macrobiotus occidentalis striatus Dastych, 1974, and Macrobiotus kristenseni Guidetti, Peluffo, Rocha, Cesari \& Moly de Peluffo, 2013, also have eggs with annulations on the processes; however, in the first species their bases are surrounded with a wreath of several small points (Dastych, 1974), and in M. kristenseni the annulation is only visible in SEM.

Differential diagnosis by the presence of similar star-shaped pores in the cuticle, this species is most similar to Minibiotus pseudostellarus Roszkowska, Stec, Ciobanu \& Kaczmarek, 2016, Minibiotus constellatus Michalczyk \& Kaczmarek, 2003, Minibiotus eichhorni Michalczyk \& Kaczmarek, 2004, Minibiotus sidereus Pilato, Binda \& Lisi, 2003, Minibiotus claxtonae
Rossi, Claps \& Ardohain, 2009 and Minibiotus aculeatus (Murray, 1910).

Minibiotus pentannulatus sp. nov. differs from M. pseudostellarus by having a smaller body size $(144-258 \mu \mathrm{m}$ in M. pentannulatus sp. nov. and $241-320 \mu \mathrm{m}$ in M. pseudostellarus), an absence of eye-spots, and the presence of 4 types of pores. In contrast, M. pseudostellarus possesses only 2 types, rounded and pseudo-star shaped. Rounded/oval pores reach bigger sizes $(0.49-1.57 \mu \mathrm{m}$ in the holotype of $M$. pentannulatus sp. nov. and $0.3-0.9 \mu \mathrm{m}$ in the holotype of $M$. pseudostellarus). Despite the overlapping in the size of the starshaped pores between the 2 species, the smallest pores of $M$. pentannulatus sp. nov. are much larger than the smallest $M$. pseudostellarus (1.35-2.66 $\mu \mathrm{m}$ and $0.6-2.5 \mu \mathrm{m}$, respectively, in the holotypes). Star-shaped pores with 5-6 points are grouped on the cephalic and caudal portion and on the legs, while in M. pseudostellarus, these pores are present only on the legs. Shorter and narrower buccal tube, [7.9-9.3] in M. pentannulatus sp. nov. vs. [10.2-11.6] in M. pseudostellarus, respectively. Level of the stylet support insertion point in a more anterior position (11.4-16.0 $\mu \mathrm{m}$ [57.6-61.7] in M. pentannulatus sp. nov. and 16.1-19.3 $\mu \mathrm{m}$ [65.6-68.8] in M. pseudostellarus). Macroplacoid length sequence $1>2>3$ while in M. pseudostellarus is $3>2 \geq 1$. Microplacoid smaller $(0.8-1.1 \mu \mathrm{m}$ [3.1-4.5] in $M$. pentannulatus sp. nov. vs. $1.1-1.5 \mu \mathrm{m}$ [4.5-5.7] in $M$. pseudostellarus). Macroplacoid row and entire placoid row shorter (4.7-8.3 $\mu \mathrm{m}$ [25.1-31.5] and 6.0-9.2 $\mu \mathrm{m}$ [29.7-34.6] in M. pentannulatus sp. nov. vs. 8.7-11.0 $\mu \mathrm{m}$ [35.5-38.9] and 
Table 1

Measurements and $p t$ values of selected morphological structures of the holotype and paratypes of Minibiotus pentannulatus sp. nov.

\begin{tabular}{|c|c|c|c|c|c|c|c|c|c|c|c|c|c|}
\hline \multirow[t]{2}{*}{ Character } & \multirow[t]{2}{*}{$N$} & \multicolumn{6}{|c|}{ Range } & \multicolumn{2}{|c|}{ Mean } & \multicolumn{2}{|c|}{$\mathrm{SD}$} & \multicolumn{2}{|c|}{ Holotype } \\
\hline & & $\mu \mathrm{m}$ & & & $p t$ & & & $\mu \mathrm{m}$ & $p t$ & $\mu \mathrm{m}$ & $p t$ & $\mu \mathrm{m}$ & $p t$ \\
\hline Body length & 23 & 144 & - & 258 & & & & 214 & & 29 & & 206 & \\
\hline \multicolumn{14}{|l|}{ Buccopharyngeal tube } \\
\hline Buccal tube length & 23 & 18.7 & - & 27.6 & & & & 25.0 & & 1.6 & & 27.6 & \\
\hline Stylet support insertion point & 23 & 11.4 & - & 16.0 & 57.6 & - & 61.7 & 15.1 & 60.3 & 1.0 & 1.0 & 15.9 & 57.6 \\
\hline Buccal tube external width & 23 & 1.5 & - & 2.4 & 7.9 & - & 9.3 & 2.1 & 8.5 & 0.2 & 0.4 & 2.3 & 8.3 \\
\hline Buccal tube internal width & 18 & 0.6 & - & 1.6 & 3.0 & - & 5.9 & 1.1 & 4.3 & 0.2 & 0.8 & 1.3 & 4.7 \\
\hline Ventral lamina length & 22 & 9.0 & - & 13.6 & 46.8 & - & 52.7 & 12.4 & 49.5 & 1.0 & 1.8 & 13.1 & 47.5 \\
\hline \multicolumn{14}{|l|}{ Placoid lengths } \\
\hline Macroplacoid 1 & 21 & 2.0 & - & 3.0 & 9.0 & - & 11.6 & 2.5 & 10.1 & 0.2 & 0.7 & 3.0 & 10.9 \\
\hline Macroplacoid 2 & 23 & 1.4 & - & 2.5 & 6.9 & - & 9.5 & 2.0 & 7.8 & 0.3 & 0.7 & 2.5 & 9.1 \\
\hline Macroplacoid 3 & 22 & 1.4 & - & 2.3 & 6.6 & - & 8.7 & 1.8 & 7.4 & 0.2 & 0.5 & 2.1 & 7.6 \\
\hline Microplacoid & 18 & 0.8 & - & 1.1 & 3.1 & - & 4.5 & 1.0 & 3.9 & 0.1 & 0.4 & 0.9 & 3.3 \\
\hline Macroplacoid row & 20 & 4.7 & - & 8.3 & 25.1 & - & 31.5 & 6.9 & 27.7 & 0.8 & 1.8 & 8.0 & 29.0 \\
\hline Placoid row & 17 & 6.0 & - & 9.2 & 29.7 & - & 34.6 & 7.9 & 31.9 & 0.8 & 1.5 & 9.2 & 33.3 \\
\hline \multicolumn{14}{|l|}{ Claw 1 lengths } \\
\hline External primary branch & 16 & 4.3 & - & 6.4 & 21.3 & - & 24.8 & 5.7 & 23.1 & 0.5 & 0.9 & 6.3 & 22.8 \\
\hline External secondary branch & 9 & 3.1 & - & 4.8 & 16.1 & - & 18.8 & 4.3 & 17.6 & 0.5 & 0.9 & $?$ & $?$ \\
\hline Internal primary branch & 17 & 4.1 & - & 6.3 & 21.7 & - & 23.9 & 5.7 & 23.0 & 0.5 & 0.7 & 6.3 & 22.8 \\
\hline Internal secondary branch & 14 & 2.9 & - & 4.7 & 15.7 & - & 18.4 & 4.3 & 17.4 & 0.5 & 0.7 & 4.6 & 16.7 \\
\hline \multicolumn{14}{|l|}{ Claw 2 lengths } \\
\hline External primary branch & 19 & 5.7 & - & 6.7 & 22.8 & - & 26.1 & 6.2 & 24.4 & 0.3 & 1.1 & 6.3 & 22.8 \\
\hline External secondary branch & 14 & 4.5 & - & 5.3 & 16.7 & - & 21.0 & 4.8 & 19.0 & 0.3 & 1.3 & 4.6 & 16.7 \\
\hline Internal primary branch & 17 & 5.8 & - & 6.6 & 22.1 & - & 26.0 & 6.2 & 24.3 & 0.2 & 1.1 & 6.1 & 22.1 \\
\hline Internal secondary branch & 16 & 4.5 & - & 5.4 & 18.0 & - & 21.2 & 5.0 & 19.6 & 0.3 & 1.0 & $?$ & $?$ \\
\hline \multicolumn{14}{|l|}{ Claw 3 lengths } \\
\hline External primary branch & 17 & 4.5 & - & 6.6 & 22.1 & - & 26.3 & 6.1 & 24.5 & 0.5 & 1.1 & 6.1 & 22.1 \\
\hline External secondary branch & 14 & 4.0 & - & 5.5 & 17.5 & - & 22.0 & 4.9 & 19.3 & 0.4 & 1.2 & 4.9 & 17.8 \\
\hline Internal primary branch & 17 & 4.5 & - & 6.6 & 22.5 & - & 25.9 & 6.0 & 24.1 & 0.5 & 1.0 & 6.2 & 22.5 \\
\hline Internal secondary branch & 9 & 3.2 & - & 5.1 & 17.1 & - & 19.8 & 4.5 & 18.2 & 0.5 & 0.9 & $?$ & $?$ \\
\hline \multicolumn{14}{|l|}{ Claw 4 lengths } \\
\hline Anterior primary branch & 11 & 5.2 & - & 7.5 & 26.2 & - & 29.2 & 6.8 & 27.2 & 0.6 & 0.9 & 7.5 & 27.2 \\
\hline Anterior secondary branch & 10 & 3.6 & - & 5.9 & 19.2 & - & 22.2 & 5.1 & 20.5 & 0.6 & 1.0 & 5.9 & 21.4 \\
\hline Posterior primary branch & 9 & 6.7 & - & 7.6 & 27.4 & - & 28.9 & 7.1 & 27.9 & 0.3 & 0.5 & 7.6 & 27.5 \\
\hline Posterior secondary branch & 6 & 5.2 & - & 6.0 & 20.9 & - & 23.0 & 5.6 & 21.8 & 0.3 & 0.7 & 6.0 & 21.7 \\
\hline
\end{tabular}

10.4-13.0 $\mu \mathrm{m}$ [42.2-46.2] in M. pseudostellarus, respectively). Slightly smaller claws and cuticular bar absent in $M$. pentannulatus sp. nov. It was not possible to compare the eggs between these 2 species, because in $M$. pseudostellarus eggs are unknown.

Minibiotus pentannulatus sp. nov. differs from $M$. constellatus by having the star-shaped pores with up to 6 tips $(M$. constellatus up to 7) grouped on the cephalic and caudal portion, and on the legs in the new species while in M. constellatus they are distributed randomly, but 2 rows are arranged along the main axis of the body. Fine granulation only present on leg IV while in $M$. constellatus, it is present on all legs. It was not possible to compare the eggs between these 2 species because there is no information about $M$. constellatus eggs.

Minibiotus pentannulatus sp. nov. differs from M. eichhorni by the absence of eye-spots. Star-shaped pores more common in the new species, with 5-6 tips, while rare in M. eichhorni, in which they are mostly trilobated and quadrilobated, and with no more than 5 tips. In the new species, the multi-lobated and star shaped pores are distributed on the cephalic and caudal extremities of the body, and in 8 transverse rows in juveniles (randomly in subsequent life stages), while in $M$. eichhorni those pores are arranged on the dorsal cuticle in 6 transverse bands as well as on the cephalic and caudal part of the body. However, the number of 'stars' rises on the caudal extremity. Stylet support insertion point more anteriorly (11.4-16.0 $\mu \mathrm{m}$ [57.6-61.7] in M. pentannulatus sp. nov. and 16.2-23.8 $\mu \mathrm{m}$ [65.4-70.6] in M. eichhorni). Macroplacoid length sequence $1>2>3$, while in M. eichhorni it is $1>3>2$. Microplacoid smaller (0.8-1.1 $\mu \mathrm{m}$ [3.1-4.5] in M. pentannulatus sp. nov. vs. 1.1-1.9 $\mu \mathrm{m}$ [4.6-6.1] in M. eichhorni). Macroplacoid row and placoid row shorter (4.7-8.3 $\mu \mathrm{m}$ [25.1-31.5] and 6.0-9.2 $\mu \mathrm{m}$ [29.7-34.6] vs. 7.6-12.8 $\mu \mathrm{m}$ [29.3-39.7] and 9.0-14.3 $\mu \mathrm{m}$ [36.2-44.1] in M. eichhorni, respectively). Smaller claws on all pairs of legs (e.g., claw I primary branch [21.3-24.8] in $M$. pentannulatus sp. nov. vs. [25.9-31.0] in M. eichhorni). Fine granulation only present on leg IV whereas in $M$. eichhorni it is present on all legs. It was not possible to compare the eggs 
between these 2 species because the eggs of $M$. eichhorni have not been described.

Minibiotus pentannulatus sp. nov. differs from $M$. sidereus by the absence of eye-spots. Multi-lobated and star-shaped pores with 3-6 tips (3-8 tips in M. sidereus). Multi-lobated and starshaped pores distributed randomly (except from the first life stage); in $M$. sidereus the star-shaped pores are absent in the intersegmental folds and form transversal bands. The largest star-shaped pores in $M$. pentannulatus sp. nov. are smaller, up to $2.8 \mu \mathrm{m}$, while in $M$. sidereus they are up to $3.9 \mu \mathrm{m}$. They are grouped on the cephalic and caudal portion and on all the legs while in $M$. sidereus the large pores are present on the head and legs, and the largest are present on the IV pair of legs. Buccal tube wider (1.5-2.4 $\mu \mathrm{m}$ [7.9-9.3] in M. pentannulatus sp. nov. and 1.0-1.7 $\mu \mathrm{m}$ [4.7-6.4] in M. sidereus). Macroplacoid length sequence $1>2>3$, whereas $M$. sidereus $1>3>2$. Egg without filaments on their tips (longer conical, sharpened, with a flexible terminal portion rarely bifurcate in $M$. sidereus). Shorter processes (up to $4.9 \mu \mathrm{m}$ in $M$. pentannulatus sp. nov. and $9.5 \mu \mathrm{m}$ in $M$. sidereus) with smaller basal width (up to $4.5 \mu \mathrm{m}$ in $M$. pentannulatus sp. nov. and $5.3 \mu \mathrm{m}$ in $M$. sidereus). Different type and number of annulations on the processes ( 5 annulations in $M$. pentannulatus sp. nov.which are actually protruding ridges and 6-7 in $M$. sidereus which are weakly outlined folds appearing as dark lines).

Minibiotus pentannulatus sp. nov. differs from M. claxtonae by the absence of eye-spots. Rounded/oval pores may be above $1 \mu \mathrm{m}$ in diameter (nearly $1 \mu \mathrm{m}$ in $M$. claxtonae). In the new species the pores are randomly distributed in adult specimens; unlike in M. claxtonae the pores form 10 transverse bands and specifically the star-shaped are aligned in longitudinal rows. Fine granulation only present on pair leg IV (on all legs in M. claxtonae). Macroplacoid length with sequence $1>2>3$, while $3>1>2$ in $M$. claxtonae. Smaller eggs $(74.2 \mu \mathrm{m}$ in $M$. pentannulatus $\mathrm{sp}$. nov. and $82-86 \mu \mathrm{m}$ in $M$. claxtonae, including the processes) with more processes (circumference 27 and hemisphere 147 in M. pentannulatus sp. nov. vs. circumference ca. 22 and hemisphere nearly 62 in $M$. claxtonae). Trunco-conical processes (egg cup shape in $M$. claxtonae), smaller (4.6-4.9 $\mu \mathrm{m}$ in $M$. pentannulatus sp. nov. and $7 \mu \mathrm{m}$ in $M$. claxtonae) and narrower in the base $(4.1-4.5 \mu \mathrm{m}$ in $M$. pentannulatus sp. nov. and ca. $5 \mu \mathrm{m}$ in $M$. claxtonae).

Minibiotus pentannulatus sp. nov. differs from M. aculeatus by the absence of eye-spots. Without processes or appendices over cuticle (with 2-6 soft conical dorsal processes in pairs on the segments over II-IV pairs of legs in M. aculeatus). Teeth in the oral cavity present in M. aculeatus. Eggs with trunco-conical processes while in $M$. aculeatus they have slender conical processes with flexible points.

\section{Acknowledgements}

We thank Kevin Ramírez Roncallo for the lichen identifications, and Dr. Marcela Bolaños and Joseph Dunn who kindly improved the English of the manuscript. This work was carried out in the framework of the research project "Composición taxonómica de flora y fauna anhidrobiótica en micro-doseles de la Sierra Nevada de Santa Marta", supported by Departamento Administrativo de Ciencia, Tecnología e Innovación "COLCIENCIAS" (\#0091288) and the Universidad del Magdalena (BIO-659/2014). This is a scientific contribution number 5 from the Centro de Colecciones Biológicas de la Universidad del Magdalena.

\section{References}

Abe, W., \& Takeda, M. (2000). A new Calcarobiotus (Tardigrada: Macrobiotidae) from the Imperial Palace of Japan. Zoological Science, 17, 259-263.

Binda, M., \& Pilato, G. (1992). Minibiotus furcatus, nuova posizione sistematica per Macrobiotus furcatus Ehrenberg, 1859, e descrizione di due nuove specie (Eutardigrada). Animalia, 19, 111-120.

Caicedo, M., Londoño, R., \& Quiroga, S. (2014). Catálogo taxonómico de los ositos de agua (Tardigrada) de la cuenca baja de los ríos Manzanares y Gaira, Santa Marta Colombia. Boletín Científico Museo de Historia Natural Universidad de Caldas, 18, 197-209.

Claxton, S. (1998). A revision of the genus Minibiotus (Tardigrada: Macrobiotidae) with description of eleven new species from Australia. Record of Australian Museum, 50, 125-160.

Dastych, H. (1974). North Korean Tardigrada. Acta Zoologica Cracoviensia, 19 , 125-146.

Degma, P., Bertolani, R., \& Guidetti, R. (2017). Actual checklist of Tardigrada species (2009-2017, 31th Edition: 15-09-2017). Available from http://www. tardigrada.modena.unimo.it/miscellanea/Actual\%20checklist\%20of\%20 Tardigrada.pdf Accessed 03.10.17

Guidetti, R., Peluffo, J. R., Rocha, M. A., Cesari, M., \& Moly de Peluffo, M. C. (2013). The morphological and molecular analyses of a new South American urban tardigrade offer new insights on the biological meaning of the Macrobiotus hufelandi group of species (Tardigrada: Macrobiotidae). Journal of Natural History, 47, 409-2426.

Heinis, F. (1914). Die moosfauna Columbiens in voyage d'exploration scientifique en Colombie. Mémoires de la Société des Sciences Naturelles de Neuchatel, 5, 675-730.

Kaczmarek, Ł., Michalczyk, Ł., \& McInnes, S. J. (2015). Annotated zoogeography of non-marine Tardigrada Part II: South America. Zootaxa, 3923, $1-107$.

Lisi, O., Daza, A., Londoño, R., \& Quiroga, S. (2017). Echiniscidae from the Sierra Nevada de Santa Marta Colombia, new records and a new species of Bryodelphax Thulin, 1928 (Tardigrada). Zookeys, 703, 1-14.

Lisi, O., Londoño, R., \& Quiroga, S. (2014). Tardigrada from a Sub-Andean forest in the Sierra Nevada de Santa Marta (Colombia) with the description of Itaquascon pilatoi sp. nov. Zootaxa, 3841, 551-562.

Londoño, R., Daza, A., Caicedo, M., Quiroga, S., \& Kaczmarek, Ł. (2015). The genus Milnesium (Eutardigrada: Milnesiidae) in the Sierra Nevada de Santa Marta (Colombia), with the description of Milnesium kogui sp. nov. Zootaxa, 3955, 561-568

Melo, J., Beltrán-Pardo, E., Bernal, J., \& Kaczmarek, Ł. (2015). New records of tardigrades from Colombia (Guatavita Cundinamarca Department). Turkish Journal of Zoology, 38, 1-9.

Meyer, H., \& Hinton, J. (2009). The Tardigrada of Southern Africa, with the description of Minibiotus harrylewisi, a new species from KwaZuluNatal, South Africa (Eutardigrada: Macrobiotidae). African Invertebrates, 50, 255-268.

Michalczyk, Ł., \& Kaczmarek, Ł. (2003). Minibiotus constellatus, a new species of Tardigrada from Peru (Eutardigrada: Macrobiotidae). Genus, 14, 295-305.

Michalczyk, Ł., \& Kaczmarek, Ł. (2004). Minibiotus eichhorni, a new species of tardigrada (Eutardigrada: Macrobiotidae) from Peru. Annales Zoologici (Warszawa), 54, 673-676.

Murray, J. (1910). Tardigrada. British Antarctic Expedition 1907-1909. Reports on the Scientific Investigations, 1-Biology (Part V).

Pilato, G. (1981). Analisi di nuovi caratteri nello studio degli Eutardigradi. Animalia, 8, 51-57. 
Pilato, G., \& Binda, M. (2010). Definition of families, subfamilies, genera and subgenera of the Eutardigrada, and keys to their identification. Zootaxa, 2404, 1-54.

Pilato, G., Binda, M., \& Lisi, O. (2003). Remarks on some species of tardigrades of South America with the description of Minibiotus sidereus n. sp. Zootaxa, 195, 1-8.

Pilato, G., Binda, M., \& Lisi, O. (2004a). Notes on some tardigrades from Thailand, with description of two new species. New Zealand Journal of Zoology, 31, 319-325.

Pilato, G., Binda, M., \& Lisi, O. (2004b). Notes on tardigrades of the Seychelles with the description of three new species. Italian Journal of Zoology, 71, $171-178$.
Rossi, G., Claps, M., \& Ardohain, D. (2009). Tardigrades from northwestern Patagonia (Neuquén Province Argentina) with the description of three new species. Zootaxa, 2095, 21-36.

Roszkowska, M., Stec, D., Ciobanu, D. A., \& Kaczmarek, Ł. (2016). Tardigrades from Nahuel Huapi National Park (Argentina South America) with descriptions of two new Macrobiotidae species. Zootaxa, 4105, 243-260.

Stec, D., Roszkowska, M., Kaczmarek, Ł., \& Michalczyk, Ł. (2017). Paramacrobiotus lachowskae, a new species of Tardigrada from Colombia (Eutardigrada: Parachela: Macrobiotidae). New Zealand Journal of Zoology, http://dx.doi.org/10.1080/03014223.2017.1354896 